\title{
Učinci uvodenja metodologije Europskoga sustava računa 2010 na statistiku javnib financija u Hrvatskoj
}

\author{
Mateja Tomek* \\ Ana Andabaka*

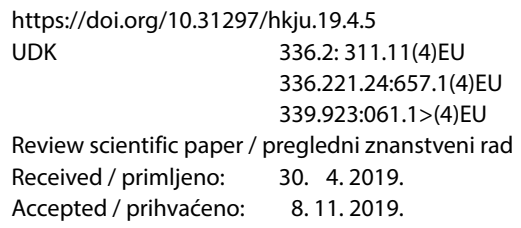

Primjena novoga metodološkog okvira u Hrvatskoj počela je u rujnu 2014., što se znatno odrazilo na statističke podatke koji odražavaju stanje javnih financija. Cilj je ovog rada utvrditi najvažnije promjene koje se odnose na obuhvat opće države, odnosno sektorsku klasifikaciju pojedinih institucijskih jedinica unutar javnoga sektora te kvantificirati utjecaj primjene nove metodologije na fiskalnu poziciju Republike Hrvatske od 2009. do 2015. Brojčane vrijednosti odstupanja fiskalnih pokazatelja utvrđuju se usmail.com).

* Mateja Tomek, Bruxelles, Belgija (Brussels, Belgium, e-mail: matejatomek@hot-

** Doc. dr. sc. Ana Andabaka, docentica, Ekonomski fakultet Sveučilišta u Zagrebu, Hrvatska (Assistant Professor, Faculty of Economics and Business, University of Zagreb, Croatia, e-mail: aandabaka@efzg.hr).

ORCID ID: https://orcid.org/0000-0003-2596-0561 
poredbom podataka koji su dostavljeni Europskoj komisiji prema metodologiji ESA 95 te podataka koji su dostavljeni nakon implementacije metodologije ESA 2010. Usporedba metodoloških okvira i podataka upućuje na znatna odstupanja koja su rezultirala povećanjem iznosa javnoga duga, ali je primjena nove metodologije istodobno omogućila bolji uvid u glavne izvore fiskalnih rizika te pružila precizniju sliku financijskog položaja javnoga sektora. Poboljšanje fiskalne pozicije ostvareno povećanjem proračunskih prihoda, kontrolom proračunskih rashoda i gospodarskim rastom omogućilo je Hrvatskoj izlazak iz postupka u slučaju prekomjernoga deficita.

Ključne riječi: ESA 2010, institucijske jedinice, javne financije, opća država, sektorizacija

\section{Uvod}

Statistika javnih financija omogućava pregled ekonomskih aktivnosti opće države te pruža uvid u fiskalnu poziciju države na temelju pokazatelja koji su ključni za utvrđivanje gospodarskog stanja u zemlji. Usporedba stanja javnih financija zahtijeva dosljednu primjenu metodološkoga okvira koji definira obuhvat javnoga sektora i sektorsku klasifikaciju institucijskih jedinica. Statistički ured Europske unije, u suradnji s nacionalnim zavodima za statistiku država članica Europske unije (EU), objavio je 1970. dokument pod nazivom Europski sustav integriranih ekonomskih računa radi stvaranja sustava nacionalnih računa koji ispunjava zahtjeve ekonomske i socijalne politike Europske unije (Regulation (EU) No 549/2013, str. 1). Taj dokument naknadno je ažuriran 1979., a zamijenila ga je primjena europskog sustava nacionalnih i regionalnih računa - ESA 95, od 1996. Tijekom primjene metodologije ESA 95 došlo je do znatnih promjena povezanih s načinom poslovanja gospodarskih subjekata te se pod utjecajem globalizacije ekonomskih aktivnosti razvila potreba za promjenom načina statističkog praćenja, posebice međunarodnih transakcija, kako bi se preciznije i kvalitetnije kreirali podatci vezani za ekonomske nacionalne račune. Zamjena i revizija ESA 95 ostvarena je uvođenjem novoga metodološkog okvira za proizvodnju podataka nacionalnih računa ESA 2010, koji je u primjeni od rujna 2014. (Regulation (EU) No 549/2013). 
Europski sustav računa 2010 uspostavljen je Uredbom Europskog parlamenta i Vijeća br. 549/2013 o Europskom sustavu nacionalnih i regionalnih računa u Europskoj uniji, koja detaljno propisuje primjenu nove metodologije. Metodologija ESA 2010 ima istu strukturu kao i ESA 95 za prvih 13 poglavlja te je potrebno naglasiti da se ne mijenjaju njezini osnovni koncepti. Postoje velike razlike u opsegu jer je nadodano 11 novih poglavlja o satelitskim računima, državnim računima i ostatku svjetskih računa. Postoje i znatna proširenja na poglavljima o tromjesečnim računima i regionalnim računima. Nadodana poglavlja razrađuju aspekte sustava koji odražavaju promjene pri mjerenju modernih ekonomija. Statistički sustav ESA 2010 ponajprije je usmjeren na države koje su članice Europske unije, odnosno na potrebu za kreiranjem statistike nacionalnih računa u okviru Europske unije. Sustav nacionalnih i regionalnih računa prikazuje cjelovitu kvantitativnu sliku ekonomskoga razvoja, a mjera je gospodarskoga rasta kojom se nacionalni računi najčešće koriste bruto domaći proizvod (BDP). Europski sustav nacionalnih i regionalnih računa upotrebljava se za analizu i procjenu strukture ukupne ekonomije, posebnih dijelova ili aspekata ekonomije, razvoja gospodarstva tijekom vremena te razvoja ukupnoga gospodarstva u odnosu na druga gospodarstva (Regulation (EU) No 549/2013).

ESA 2010 u velikoj je mjeri kompatibilna s međunarodnom metodologijom sustava nacionalnih računa 2008 (engl. System of National Accounts - SNA 2008), koju je prihvatila Statistička komisija Ujedinjenih naroda, s obzirom na definicije, računovodstvena pravila i klasifikacije. ESA 2010 temelji se na konceptima SNA 2008, koji daju smjernice o nacionalnom računovodstvu za sve zemlje širom svijeta. Koncepti ESA 2010 pobliže su određeni i precizniji od koncepata SNA 2008. ESA 2010 sadržava odvojena poglavlja o transakcijama proizvodima, distributivnim transakcijama i financijskim transakcijama. Nasuprot tomu, SNA 2008 te transakcije navodi i objašnjava u poglavljima uređenim računima, npr. poglavlja na računu proizvodnje, računi primarne raspodjele dohotka, kapitalni račun i račun sektora inozemstva. ESA 2010 opisuje koncepte dajući definiciju i popis onoga što je uključeno i što je isključeno, dok SNA 2008 opisuje pojmove općenito uz obrazloženje prihvaćenih konvencija (Eurostat, 2013, str. 10).

Uvođenje ESA 2010 omogućilo je upotrebu referentnoga okvira zajedničkih standarda, definicija, klasifikacija i računovodstvenih pravila pri izradi nacionalnih računa kako bi se postigla usporedivost rezultata između država članica i na razini EU-a (Regulation (EU) No 549/2013, str. 2). Bitno je istaknuti da se primjena standarda metodologije ESA 2010 odno- 
si na tri bitna područja koja obuhvaćaju statistiku odnosa s inozemstvom, statistiku javnoga duga te monetarnu statistiku. Uvođenje standarda ESA 2010 za statistiku odnosa s inozemstvom omogućilo je usklađivanje s metodologijom koju propisuje šesto izdanje Priručnika za platnu bilancu $(B a-$ lance of Payments and International Investment Position Manual - BPM6), a nova sektorska klasifikacija institucijskih jedinica usklađena je sa SNA 2008, što je temeljni međunarodni statistički standard (HNB, 2016).

U radu se istražuju učinci uvođenja metodologije ESA 2010 u Hrvatskoj te se postavljaju dva istraživačka pitanja:

Kako je metodologija ESA 2010 utjecala na sektorsku klasifikaciju pojedinib institucijskih jedinica unutar brvatskoga jarnog sektora?

Kako je metodologija ESA 2010 utjecala na podatke o visini proračunskoga deficita i jarnoga duga u Hrvatskoj?

U skladu s istraživačkim pitanjima oblikuje se hipoteza da je primjena nove metodologije sustava nacionalnih računa znatno utjecala na podatke o stanju državnih financija u Hrvatskoj. Metodologija rada sastoji se u kvalitativnom pristupu opisu nove metodologije europskoga sustava nacionalnih računa koji je posebno važan u smislu sektorske klasifikacije institucija javnoga sektora i opće države. U radu se prikazuju Eurostatovi kriteriji na temelju kojih se provodi sektorska klasifikacija institucijskih jedinica te se opisuje obuhvat sektora opće države u Hrvatskoj u skladu s navedenom metodologijom. Pritom su vrlo važni kvantitativni i kvalitativni kriterij razgraničenja između sektora opće države i drugih sektora. Posebna se pozornost pridaje promjeni, tj. resektorizaciji pojedinih institucijskih jedinica koje su na taj način postale dijelom opće države jer njihovi prihodi, rashodi i dugovi utječu na ukupne prihode i rashode proračuna opće države te visinu javnoga duga. U skladu s drugim postavljenim istraživačkim pitanjem, kako bi se kvantificirao učinak primjene nove metodologije, prikazuje se i objašnjava odstupanje podataka o državnim financijama prema novoj metodologiji od 2009. do 2015. u odnosu na podatke koje je Europska komisija objavila za isto razdoblje prema prethodno korištenoj metodologiji.

Rad se sastoji od pet dijelova. Drugi dio rada sadržava pregled literature, a u trećemu dijelu opisuju se promjene koje su proizišle iz nove sektorske klasifikacije institucijskih jedinica unutar opće države. U četvrtome dijelu analizira se utjecaj primjene nove metodologije na statistiku javnih financija u Hrvatskoj od 2009. do 2015. Diskusija je peti dio rada, a u posljednjemu dijelu sadržana su zaključna razmatranja. 


\section{Pregled literature}

Sve su članice Europske unije od rujna 2014. počele primjenjivati novu metodologiju, što je dovelo do revizije podataka o proračunskome manjku i javnome dugu. Eurostat (2014c, str. 4) navodi da su općenito tri ključne promjene u primjeni metodologije ESA 2010 povezane s pravilima sektorske klasifikacije, statističkim tretmanom transfera povezanih s mirovinskim sustavom te izuzimanjem kamata iz swap i forward ${ }^{1}$ ugovora iz izračuna proračunskoga manjka. Casey (2014, str. 7-8) potvrđuje da su u Irskoj glavne promjene navedenih pokazatelja prouzročene promjenama $\mathrm{u}$ sektorskoj klasifikaciji institucijskih jedinica, statističkim tretmanom tijekova kamata iz ugovora swap i forward te prebacivanjem obveza povezanih s mirovinskim osiguranjem na državu. Reklasifikacija banke u državnome vlasništvu Irish Bank Resolution Corporation u sektor središnje države imala je najveći utjecaj na povećanje javnoga duga od 2011. do 2013. (Casey, 2014, str. 7). Prema podatcima Eurostata (2014c, str. 9), to je povećanje iznosilo 12,2 postotna boda u 2011., 10,3 postotna boda u 2012. i 7,2 postotna boda u 2013. Zbog promjene statističkoga tretmana došlo je do isključivanja kamata iz swap i forward ugovora i za zemlje u postupku u slučaju prekomjernoga deficita, što je utjecalo na smanjenje irskoga deficita od 2010. do 2013. Obveze za mirovinsko osiguranje sveučilišta i određenih javnih društava (engl. semi-state bodies) prebačene su na državu u 2009. i 2010. godini. Prema ESA 95 to je utjecalo na smanjenje deficita jer su ostvareni dodatni prihodi od povezane imovine. Međutim, prema ESA 2010 navedeni transferi povećavaju deficit kada obveze premašuju imovinu mirovinskoga fonda, što je rezultiralo povećanjem deficita za 1 postotni bod u 2009. te za 1,5 postotnih bodova u 2010. u odnosu na podatke prema ESA 95 (Casey, 2014, str. 8).

Belgijska središnja banka (National Bank of Belgium, 2014, str. 50-51) objavila je podatke o proračunskome deficitu i javnome dugu prema ESA 95 i ESA 2010 za razdoblje od 2010. do 2013. Odstupanja vrijednosti prikazala je u tri skupine promjena koje su obuhvaćale promjene proizišle samo iz primjene metodologije ESA 2010, metodološke promjene povezane s uvođenjem nove metodologije i preispitivanjem određenih statističkih tretmana te „ostale promjene“ koje su se odnosile na ispravak

${ }^{1}$ Swap ugovor ili ugovor o razmjeni ugovor je kojim su dvije strane ugovorile razmjenu utvrđenih vrijednosti (novčanih tokova) na određeno razdoblje, dok je forward ugovor ili forvard nestandardizirani terminski ugovor koji se odnosi na odgođenu isporuku financijskih instrumenata ili robe (HNB, 2018, str. 24). 
prijašnjih pogrešaka, promjene u metodama izračuna i izvorima podataka te korištenje novijim osnovnim podatcima. Metodološke promjene povezane s uvođenjem metodologije ESA 2010 i preispitivanjem određenih statističkih tretmana odnosile su se na usklađivanje s novom metodologijom u pitanjima koja nisu prethodno potpuno razriješena, nego su naknadno diskusije na razini Europske unije dovele do konačnog rješenja. U Belgiji se u promatranome razdoblju udio deficita proračuna opće države u BDP-u povećao u rasponu od 0 do 0,3 postotna boda (u apsolutnom iznosu za 687,1 do 1.541 milijun eura), a udio javnoga duga u BDP-u povećao se u rasponu od 2,9 do 3,3 postotna boda (u apsolutnome iznosu za 20,4 do 26,1 milijardu eura). Pritom treba napomenuti da su odstupanja izražena udjelom u BDP-u bila ublažena pozitivnim učinkom implementacije metodologije ESA 2010 na reviziju vrijednosti BDP-a.

Finska je zanimljiv primjer jer je zbog revizije podataka u istome razdoblju došlo do povećanja deficita i smanjenja javnoga duga. Prihvaćanjem metodologije ESA 2010 u 2013. pet javnih društava i njihovih podružnica reklasificirano je u podsektor središnje države i 150 javnih društva u podsektor lokalne države (Hansen et al., 2015, str. 15-16). Navedena reklasifikacija, u kombinaciji s promjenama tretmana određenih stavaka, kao što su tijekovi kamata iz swap i forward ugovora, dovela je do povećanja deficita proračuna opće države u 2013. s 2,1 \% BDP-a prema metodologiji ESA 1995 na 2,4 \% BDP-a prema ESA 2010 (Hansen et al., 2015, str. 16). Tako se na kraju 2013. udio deficita u BDP-u povećao za 0,3 postotna boda, a udio javnoga duga u BDP-u smanjio za 1 postotni bod (Hansen et al., 2015, str. 27).

Fiskalne rizike državnih jamstava u Hrvatskoj i Europskoj uniji opisuju Primorac i Župančić (2015). U radu analiziraju vrijednost i strukturu izdanih državnih jamstava u Hrvatskoj s naglaskom na njihov utjecaj na povećanje javnoga duga u kontekstu metodoloških promjena u statistici državnih financija. Analizom podataka o javnom dugu i jamstvima od 2009. do 2013. utvrdili su da je primjenom metodologije ESA 2010 došlo do istodobnoga povećanja javnoga duga te smanjenja iznosa izdanih državnih jamstava, odnosno da je u velikoj mjeri dio potencijalnoga duga pretvoren u izravni dug države. Zaključno navode da je država izdavanjem jamstava podupirala poduzeća koja su ostvarivala gubitke, što se u konačnici odrazilo na povećanje javnoga duga. Potencijal pretvaranja u javni dug u određenim slučajevima imaju i obveze iz ugovora o javno-privatnom partnerstvu i koncesijama. Bajo i Juričić (2015) opisuju statistički tretman tih obveza u skladu s metodologijom ESA 2010. Navode da se država koristi oblicima financiranja kapitalnih investicija u suradnji s privatnim partnerom u uvjetima nedostatnih proračunskih prihoda i postojećih proračunskih manjkova, ali upozoravaju da 
se takvo financiranje može tretirati kao neizravno državno zaduživanje. Naime, ako država snosi većinu rizika investicije (više od 50 \%), tada se imovina projekta pripisuje kreditima i zajmovima koje je primila država, odnosno u slučaju klasificiranja projekta u bilancu države dolazi do povećanja javnoga duga u iznosu ukupne vrijednosti imovine projekta. Bajo i Juričić (2015, str. 3) naglašavaju da je za utjecaj na javni dug ključan sadržaj ugovora o javno-privatnom partnerstvu i koncesijama, a posebno ugovoreni potencijalni rizici za državu kao javnog partnera ili davatelja koncesije te statistička klasifikacija vlasništva imovine uključene u ugovor. Budući da ugovori nisu standardizirani, odluku o statističkome tretmanu pojedinoga ugovora te njegovu utjecaju na proračunski saldo i javni dug Hrvatske donosi Državni zavod za statistiku.

Pokretače javnoga duga od 2008. do 2014. istražuju Andabaka, Družić i Mustać (2017). Koristeći se metodologijom Europske središnje banke i Europske komisije te statističkim podatcima Europske komisije, Ministarstva financija i Hrvatske narodne banke, analiziraju doprinos pojedinih komponenata porastu javnoga duga. Povećanje javnoga duga promatraju na dva načina - preko komponenata koje su pridonijele porastu javnoga duga mjereno udjelom u BDP-u te preko komponenata koje prikazuju povećanje javnoga duga u apsolutnome iznosu u kunama. Prema analitičkome okviru održivosti javnoga duga dinamiku javnoga duga izražena visinom udjela u BDP-u prema ESA 2010 u velikoj je mjeri odredilo povećanje rashoda za kamate i kontrakcija gospodarstva promatrano kumulativnim učinkom u navedenome razdoblju. S druge strane, uzimaju u obzir uvođenje nove metodologije te promatraju kumulativno povećanje duga opće države u apsolutnome iznosu u istome razdoblju. Najvažniji učinak na visinu javnoga duga, nakon deficita proračuna opće države, imala je reklasifikacija poduzeća zbog prelaska s metodologije ESA 95 na ESA 2010, potom izvanproračunske transakcije koje su se najvećim dijelom odnosile na aktiviranje državnih jamstava te prilagodba stanja i tokova.

Galinec i Kandžija (2018) istraživali su glavne čimbenike koji su pridonijeli promjenama javnoga duga u Hrvatskoj od 2010. do 2017., osim proračunskoga manjka. Navode da je povećanje javnoga duga u 2013. prema novoj metodologiji bilo gotovo dvostruko veće od proračunskoga manjka. Osim reklasifikacije javnih poduzeća i preuzimanja dugova brodogradilišta, kao bitan čimbenik povećanja duga navode prilagodbu stanja i tokova koja je bila povezana s velikim iznosima akumulacije gotovine. Povećanje gotovine na računu državne riznice služilo je kao „pričuva“ za provođenje operacija financiranja proračunskoga manjka u 2014. (Galinec \& Kandžija, 2018, str. 222). 


\section{Sektorska klasifikacija institucijskih jedinica unutar opće države}

Prema metodologiji ESA 2010 uz prethodno korišteni kvantitativni kriterij koji se još naziva i kriterij $50 \%$, uvodi se i kvalitativni kriterij za razgraničavanje između sektora opće države i drugih sektora. Prema kvantitativnom kriteriju samo one jedinice kod kojih je udio tržišnih prihoda u ukupnim troškovima proizvodnje veći od 50 \% u dužem razdoblju, smatraju se tržišnim jedinicama, pri čemu ESA 2010 u troškove proizvodnje uključuje i troškove kapitala, tj. troškove kamata. Kvalitativni kriterij odnosi se, primjerice, na utvrđivanje posluje li institucijska jedinica zaista na tržištu i kome prodaje svoje proizvode odnosno pruža svoje usluge (DZS, 2014a). ESA 2010 naglašava kvalitativni kriterij u smislu gospodarske motivacije, neovisnosti u aktivnostima usmjerenim prema ostvarivanju dobiti ili sposobnosti otplate dugova bez državne pomoći kako bi samo neovisni subjekti koji posluju prema načelu tržišnog natjecanja bili isključeni iz obuhvata opće države (National Bank of Belgium, 2014, str. 45). Institucijske jedinice podrazumijevaju gospodarske subjekte koji mogu imati vlasništvo nad dobrima i imovinom, preuzimati obveze te obavljati gospodarske aktivnosti i transakcije s drugim subjektima (DZS, 2014a).

Kriteriji koji se koriste pri utvrđivanju kontrolira li država društvo, prema ESA 2010, odnose se na državno vlasništvo nad većinom glasačkih prava; državnu kontrolu nad upravom ili upravnim tijelom; državnu kontrolu nad imenovanjem i razrješenjem ključnog osoblja; državnu kontrolu nad ključnim odborima u subjektu; vlasništvo zlatne dionice od države; posebne propise; situacije kada je država prevladavajući kupac te pozajmljuje društvu (Eurostat, 2013, str. 33). Iako je katkad dovoljan samo jedan pokazatelj da se utvrdi državna kontrola nad institucijskom jedinicom, u drugim slučajevima više zasebnih pokazatelja zajedno dokazuje državnu kontrolu. Isto vrijedi i za kriterije koji se primjenjuju kod neprofitnih institucija koje su neovisne pravne osobe, pri čemu se pri utvrđivanju državne kontrole u obzir uzima imenovanje odgovornih osoba; odobravanje instrumenata osiguranja; ugovorne obveze s državom; stupanj državnoga financiranja te stupanj izloženosti države riziku (DZS, 2014a).

Za potrebe makroekonomske analize koja razmatra ukupne aktivnosti sličnih društava, institucijske jedinice grupiraju se u institucijske sektore, od kojih se neki dijele na podsektore (DZS, 2014a). Raspodjela institucijskih jedinica u glavne institucijske sektore polazi od utvrđivanja sektora za rezidentne jedinice, a to su one kojima je središte prevladavajućega ekonomskog interesa na gospodarskom području te zemlje, odnosno koje obavljaju 
gospodarske aktivnosti na području te zemlje jednu godinu ili više (Eurostat, 2013, str. 25-26). Prema sustavu ESA 2010 (Slika 1.) institucijske se jedinice grupiraju u sektor inozemstva (S.2) i pet domaćih institucijskih sektora koji se međusobno isključuju, a obuhvaćaju kućanstva (S.14), neprofitne institucije koje služe kućanstvima (S.15), opću državu (S.13), nefinancijska društva (S.11) i financijska društva (S.12) (Eurostat, 2013, str. 12, 31).

Slika 1. Raspodjela institucijskib jedinica u sektore prema ESA 2010

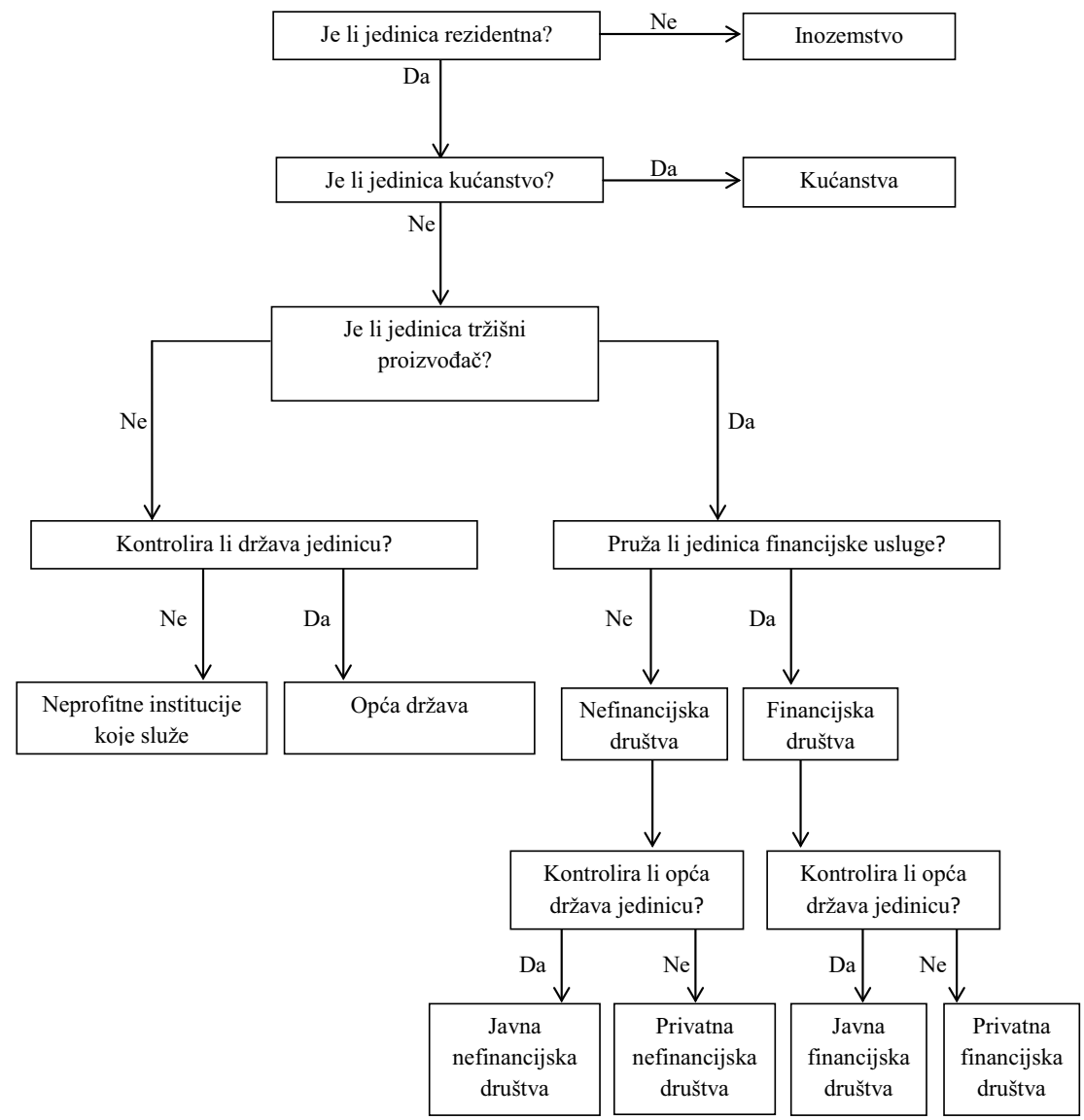

Izvor: Eurostat, http://ec.europa.eu/eurostat/web/main/home, 1995. - danas. Za prilagodbu prikaza potpuno su odgovorne autorice.

Sektor opće države sastoji se od institucijskih jedinica koje su netržišni proizvođači i čija je proizvodnja namijenjena individualnoj i zajedničkoj potrošnji, a koje se financiraju obveznim plaćanjima jedinica koje pripa- 
daju drugim sektorima te institucijskih jedinica koje ponajprije provode preraspodjelu nacionalnog dohotka i bogatstva (DZS, 2014a). Opća država (S.13) općenito se dijeli na četiri podsektora koji uključuju središnju državu (S.1311), regionalnu ili saveznu državu (S.1312), lokalnu državu (S.1313) i fondove socijalne sigurnosti (S.1314) (Eurostat, 2013, str. 31). Središnja država uključuje sve državne upravne odjele i ostale središnje agencije čija se nadležnost obično prostire na cijelo ekonomsko područje, osim upravljanja fondovima socijalne sigurnosti (DZS, 2014a). Središnja država uključuje i neprofitne institucije pod kontrolom središnje vlasti koja ih uglavnom financira (DZS, 2016, str. 4). Savezna ili regionalna država odnosi se na one vrste javne uprave koje su zasebne institucijske jedinice i obavljaju određene javne funkcije, osim upravljanja fondovima socijalne sigurnosti, na nižoj razini od središnje države, a višoj od upravnih institucijskih jedinica na lokalnoj razini (Eurostat, 2013, str. 44). U Hrvatskoj taj podsektor nije zastupljen u okviru sektora opće države, a lokalna država podrazumijeva one vrste javne uprave čija se nadležnost ograničava samo na lokalni dio ekonomskog područja, osim lokalnih agencija fondova socijalne sigurnosti (DZS, 2014a). Lokalna država obuhvaća jedinice lokalne i područne samouprave, sve korisnike lokalnih proračuna te neprofitne institucije koje su pod kontrolom lokalne vlasti i uglavnom ih ona financira (DZS, 2016, str. 4). Konačno, fondovi socijalne sigurnosti uključuju središnje, savezne i lokalne institucijske jedinice čija je primarna djelatnost pružanje socijalnih naknada, pri čemu su prema zakonu ili drugim propisima određene skupine stanovništva obvezne sudjelovati u njima ili plaćati doprinose te je opća država odgovorna za upravljanje fondovima u smislu određivanja ili odobravanja doprinosa i naknada, neovisno o svojoj ulozi nadzornog tijela ili poslodavca (Eurostat, 2013, str. 45).

Najvažnije promjene prelaska s metodološkog okvira ESA 1995 na ESA 2010 očituju se na sektoru opće države i sektoru financijskih poduzeća jer su zbog izmijenjenih kriterija sektorske klasifikacije institucijske jedinice poput javnih poduzeća s ograničenom odgovornošću reklasificirane iz sektora nefinancijskih poduzeća u sektor opće države i podsektor središnje države. Obuhvat proračuna opće države prema metodologiji ESA 95 uključivao je državni proračun i njegove korisnike, izvanproračunske korisnike (Hrvatske vode - HV, Hrvatske ceste - HC, Fond za zaštitu okoliša i energetsku učinkovitost - FZOEU, Državnu agenciju za osiguranje štednih uloga i sanaciju banaka - DAB te Agenciju za upravljanje državnom imovinom - AUDIO), javna poduzeća (Hrvatsku radioteleviziju - HRT i Hrvatske željeznice Infrastruktura - HŽI), kao i proračune jedinice lokalne i područne (regionalne) samouprave (Hrvatski sabor, 2013). 
Obuhvat proračuna opće države prema metodologiji ESA 2010 (Slika 2.) uključuje državni proračun i korisnike državnog proračuna, izvanproračunske korisnike (HV, HC, FZOEU te Centar za restrukturiranje i prodaju CERP i Državni ured za upravljanje državnom imovinom - DUUDI koji su pravni sljednici Agencije za upravljanje državnom imovinom), javna poduzeća (HRT, HŽI, Hrvatske autoceste - HAC, Autocesta Rijeka - Zagreb ARZ, Hrvatska banka za obnovu i razvitak - HBOR, Hrvatski operator tržišta energije - HROTE, Hrvatska regulatorna agencija za mrežne djelatnosti - HAKOM, Hrvatska agencija za malo gospodarstvo, inovacije i investicije - HAMAG-BICRO, Hrvatska energetska regulatorna agencija - HERA i $\mathrm{DAB}$ ), lokalne proračune te proračunske i izvanproračunske korisnike lokalnih proračuna te izvanproračunske fondove (Hrvatski zavod za zdravstveno osiguranje - HZZO, Hrvatski zavod za mirovinsko osiguranje - HZMO i Hrvatski zavod za zapošljavanje - HZZ) (Krištof, 2014; HNB, 2015).

Slika 2. Obubvat opće države u Republici Hrvatskoj u 2015. godini prema metodologiji ESA 2010

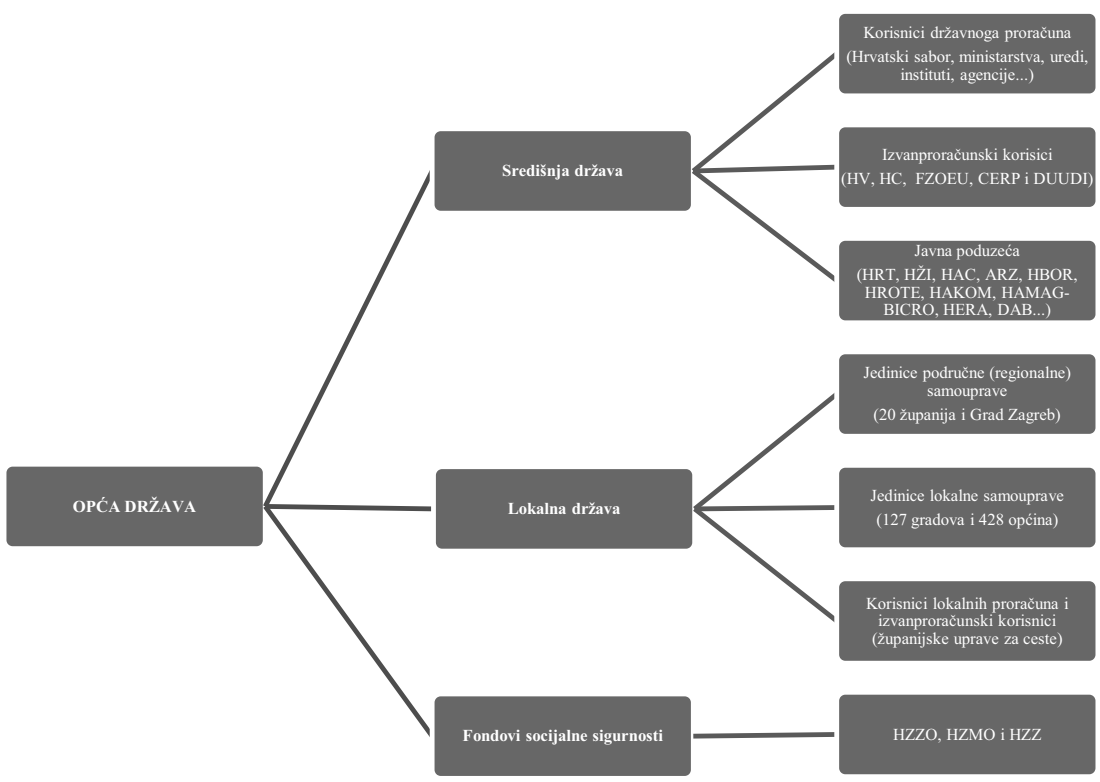

Izvor: prikaz autorica prema HNB-u (2016) i DZS-u (2016)

Tijekom primjene nove metodologije napravljena je reklasifikacija institucijskih jedinica HAC, ARZ, HROTE, HAKOM, HAMAG-BICRO i HERA iz podsektora javnih nefinancijskih društava u podsektor središnje 
države u čiji je obuhvat 2015. uključen i HBOR (Ministarstvo financija, 2015) koji je prije pripadao podsektoru javnih financijskih društava.

Pregled glavnih promjena u primjeni metodologije ESA 2010 u odnosu na ESA 95, vezano za statistički tretman transakcija u okviru državnih financija koje su utjecale na visinu salda proračuna i duga opće države, prikazuje Tablica 1. Osim šire definicije obuhvata opće države, prikazane su i druge bitne promjene koje su se odrazile na podatke o stanju državnih financija.

\section{Tablica 1. Glavne razlike izmedu metodologije ESA 95 i ESA 2010 u iska- zivanju statističkih podataka o državnim financijama}

\begin{tabular}{|c|c|}
\hline $\begin{array}{l}\text { Element } \\
\text { revizije }\end{array}$ & Razlika između metodologije ESA 95 i ESA 2010 \\
\hline $\begin{array}{l}\text { Razgra- } \\
\text { ničenje } \\
\text { između } \\
\text { privatnog, } \\
\text { javnog i } \\
\text { sektora } \\
\text { opće } \\
\text { države }\end{array}$ & 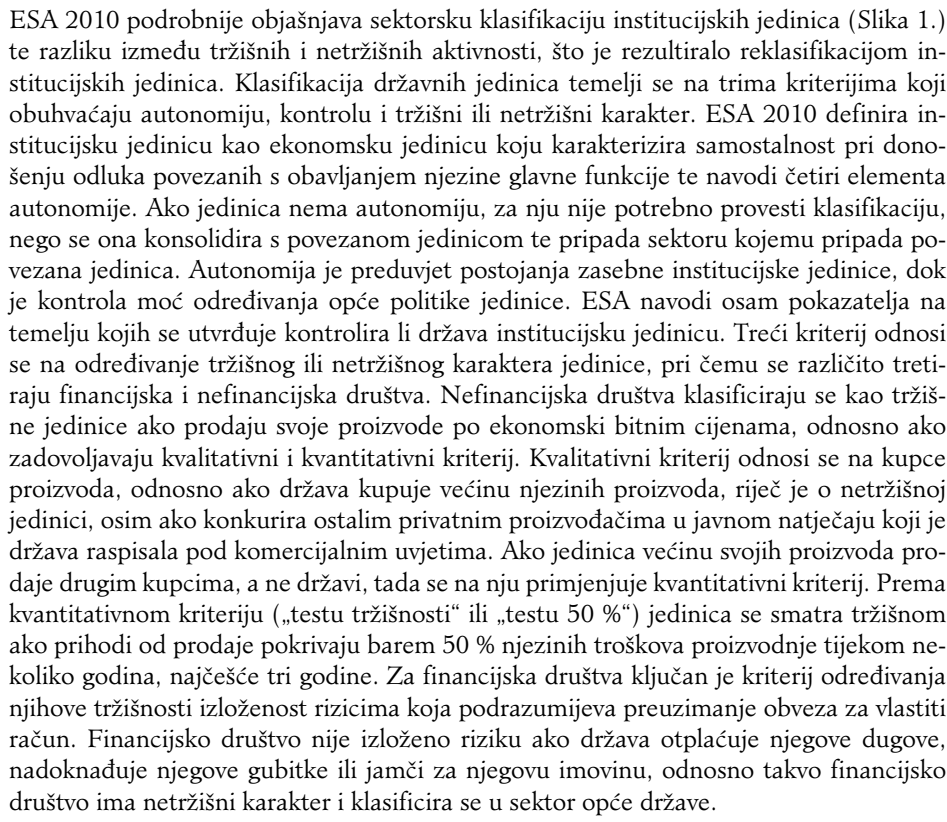 \\
\hline $\begin{array}{l}\text { Izda- } \\
\text { vanje i } \\
\text { aktivacija } \\
\text { državnih } \\
\text { jamstava }\end{array}$ & $\begin{array}{l}\text { Prema metodologiji ESA } 2010 \text { standardizirana jamstva stvarne su obveze, dok nestan- } \\
\text { dardizirana jamstava ostaju potencijalne obveze. ESA } 95 \text { na jednak je način tretirala obje } \\
\text { vrste jamstava čije izdavanje nije imalo izravan utjecaj na rashode opće države. Tek se } \\
\text { aktivacijom jamstva evidentirao kapitalni transfer između države i institucijske jedinice za } \\
\text { koju je izdano jamstvo u iznosu preuzetog duga. Standardizirana se jamstva izdaju u veliku } \\
\text { broju i uglavnom za male iznose, dok su nestandardizirana jamstva obično jednokratna } \\
\text { te nije moguće procijeniti rizik njihova izdavanja jer ne postoje usporedivi slučajevi. U } \\
\text { trenutku izdavanja standardiziranog jamstva bilježi se kapitalni transfer - rashod između } \\
\text { države i financijske institucije koja odobrava sredstva. Iznos transfera računa se na temelju } \\
\text { povijesnih podataka o nepodmirenju obveza, odnosno procjenom na temelju predviđanja } \\
\text { ako je riječ o novim aktivnostima. Kada se jamstvo aktivira, plaćanje kompenzacije finan- } \\
\text { cijskoj instituciji evidentira se kao novčana transakcija, a ne više kao rashod. }\end{array}$ \\
\hline
\end{tabular}




\begin{tabular}{|l|l|}
\hline $\begin{array}{l}\text { Tretman } \\
\text { javno- } \\
\text { privatnog } \\
\text { partner- } \\
\text { stva }\end{array}$ & $\begin{array}{l}\text { Prema metodologiji ESA } 1995 \text { infrastruktura izgrađena na temelju javno-privatnog } \\
\text { partnerstva (JPP-a) evidentirala se na računima privatnoga partnera ako je on preu- } \\
\text { zeo rizike izgradnje, potražnje i raspoloživosti. Ako država osigurava većinu financijskih } \\
\text { sredstava ili izdaje jamstva za većinu prikupljenih sredstava, tada se navedeni rizici ne } \\
\text { prenose na privatnoga partnera. ESA } 2010 \text { izričito navodi da klauzule koje osiguravaju } \\
\text { prednost isplate u slučaju raskida ugovora koji inicira privatni partner znače da rizici } \\
\text { nisu u odgovarajućoj mjeri preneseni na privatnoga partnera. Prema mišljenju Euro- } \\
\text { stata, u određivanju tretmana JPP-a potrebno je uzeti u obzir dijeljenje dobiti, javno fi- } \\
\text { nanciranje u obliku financijskih instrumenata koji su veći rizik u odnosu na instrumente } \\
\text { kojima se koristio privatni partner te različite oblike državnih jamstava. }\end{array}$ \\
\hline $\begin{array}{l}\text { Transfer } \\
\text { sredstava } \\
\text { iz drugo- } \\
\text { ga u prvi } \\
\text { mirovin- } \\
\text { ski stup }\end{array}$ & $\begin{array}{l}\text { ESA 95 je transfer sredstava državi namijenjenih budućim isplatama mirovina, kao što } \\
\text { je to slučaj kod prijenosa dijela sredstava iz drugoga u prvi mirovinski stup, priznavala } \\
\text { kada je nastao transfer, nego se oni vremenski razgraničavaju i sukcesivno priznaju u } \\
\text { prihode tijekom niza godina u skladu s predviđenom dinamikom isplate mirovina. }\end{array}$ \\
\hline $\begin{array}{l}\text { Tretman } \\
\text { kamata } \\
\text { iz swap i } \\
\text { forward } \\
\text { ugovora }\end{array}$ & $\begin{array}{l}\text { Za potrebe postupka u slučaju prekomjernoga proračunskog manjka saldo proračuna } \\
\text { opće države prema ESA 95 prilagođavao se kako bi uključivao neto kamate iz swap i } \\
\text { forward ugovora. Nakon uvođenja metodologije ESA 2010 nema više takve prilagodbe, } \\
\text { a saldo proračuna prema ESA 2010 i za potrebe postupka u slučaju prekomjernoga } \\
\text { proračunskog manjka potpuno je jednak zbog primjene jedinstvene definicije salda pro- } \\
\text { računa opće države. }\end{array}$ \\
\hline
\end{tabular}

Izvor: autorice prema Eurostatu (2013; 2014a; 2014b, str. 75) i National Bank of Belgium (2014, str. 43-49)

\section{Fiskalna pozicija Republike Hrvatske zbog primjene nove metodologije}

Statistika javnih financija odnosi se na obuhvat kategorija opće države, stoga se reklasifikacije unutar javnoga sektora kojima se određena javna poduzeća uključuju u opću državu odražavaju na kategorije prihoda i rashoda opće države, odnosno proračunski saldo te visinu javnoga duga. U ovome dijelu prikazuju se bitna odstupanja podataka o državnim financijama usporedbom vremenskih serija podataka Europske komisije o transakcijama i financijskom stanju opće države kojima se službe Komisije koriste za praćenje proračunskih pozicija članica Europske unije (European Commission, 2017). Statističke podatke o državnim financijama Komisiji su dostavili nacionalni statistički uredi uz provjeru Eurostata, pri čemu su podatci prema metodologiji ESA 95 dostupni od 2009. jer se do tada statistika javnih financija u Republici Hrvatskoj vodila samo prema metodologiji Međunarodnoga monetarnog fonda (MMF). Podatci prema metodologiji ESA 95 dostupni su do 2015. jer je od rujna 2014. svaka članica Europske unije obvezna primjenjivati metodologiju ESA 2010. 
Budući da su konačni podatci za 2014. i 2015. godinu trebali biti iskazani prema novoj metodologiji, potrebno je naglasiti da su podatci prema ESA 95 za 2014. i 2015. prognozirani (European Commission, 2014).

Podatci o manjku opće države iskazani su udjelom u BDP-u i u apsolutnome iznosu, dok su podatci o visini javnoga duga prikazani samo kao postotak BDP-a. Metodologija kojom Europska komisija procjenjuje visinu javnoga duga u apsolutnome iznosu temelji se na prilagodbi visine duga iz prethodne godine za prognozirani saldo proračuna opće države $u$ godini za koju se radi predviđanje i prognoziranu visinu prilagodbe duga i deficita. Saldo proračuna opće države temelji se na projekcijama otprilike 20 stavaka prihoda i rashoda. Kod prihodne strane proračuna u obzir se uzima povijesna elastičnost poreznih prihoda za različite vrste poreza u kombinaciji s makroekonomskim prognozama potrošnje kućanstava, stope rasta nominalnog BDP-a itd. Pritom se, kod neporeznih prihoda, uzima u obzir i planirano povlačenje sredstava iz fondova EU-a na razini opće države. Kod rashodne strane proračuna u obzir se uzimaju planirani iznosi navedeni u programu konvergencije i proračunu, kao i kapitalni transferi iz fondova EU-a u obliku javnih investicija ili promjene kamatnih stopa u kombinaciji s nedavno dospjelim ili državnim obveznicama sa skorim dospijećem.

Općenito, prognoze se temelje na pretpostavci da nije došlo do promjene u vođenju politike, pri čemu se u obzir uzimaju samo detaljne mjere koje su predviđene zakonodavstvom ili su kredibilno najavljene. Kod izražavanja pojedinih kategorija udjelom u BDP-u, procijenjene vrijednosti javnih prihoda, rashoda i javnoga duga stavljaju se u omjer s procijenjenom vrijednosti nominalnoga BDP-a koja se temelji na projekciji realnoga BDP-a i BDP deflatora. ${ }^{2}$

\subsection{Prihodi i rashodi opće države prema metodologiji ESA 2010}

ESA 2010 pri bilježenju prihoda i rashoda zahtijeva primjenu izvještavanja po obračunskom načelu za razliku od MMF-a koji primjenjuje gotovinsko načelo. Prihodi i rashodi prema obračunskom načelu bilježe se u trenutku u kojem su ostvareni, dok se prema gotovinskom načelu prihodi i rashodi

${ }^{2}$ Opis metodologije za procjenu navedenih podataka pružio je Arian Perić, ekonomski analitičar u Glavnoj upravi za ekonomska i financijska pitanja Europske komisije, elektroničkom poštom 9. srpnja 2019. 
bilježe u trenutku u kojem su primljena odnosno isplaćena sredstva (Krištof, 2015, str. 3). Hrvatski sabor prihvaća izvršenje državnoga proračuna po novčanom tijeku te je ono u fiskalnom izvješću polazna stavka izračuna za središnju državu, dok ESA 2010 uzima u obzir i promjene ostalih obveza koje se odnose na nabavu materijala i nefinancijske imovine, naknade zaposlenima itd., čiji porast rezultira većim manjkom, a smanjenje dovodi do manjeg manjka u odnosu na manjak po nacionalnoj metodologiji. Prema metodologiji ESA 2010 u izračun viška ili manjka uključuju se razlike plaćenih i obračunatih kamata. Primjenom metode vremenski prilagođena novčanog tijeka porez naplaćen u određenom razdoblju pripisuje se onom razdoblju u kojem je ostvaren na temelju određenih transakcija. Tako se porez na dohodak naplaćen u siječnju pripisuje prosincu prethodne godine, što ima priličan utjecaj kada se s početkom godine uvode važnije izmjene poreznog sustava. U prihode se ne priznaju ukupni iznosi koji su namijenjeni budućim isplatama mirovina, kao što je to slučaj kod prijenosa sredstava iz drugoga mirovinskog stupa u prvi, nego se oni vremenski razgraničavaju i sukcesivno priznaju u prihode idućih godina $u$ skladu s predviđenom dinamikom isplate mirovina (Ministarstvo financija, 2015, str. 31).

Kategorije koje prema metodologiji ESA 2010 čine državne prihode tržišna su proizvodnja, proizvodnja za vlastitu krajnju uporabu, plaćanja za netržišnu proizvodnju, porezi na proizvodnju i uvoz (primljeni), vlasnički dohodak (primljeni), tekući porezi na dohodak, bogatstvo itd., neto socijalni doprinosi, ostali tekući transferi i kapitalni transferi (primljeni). Navedeni prihodi bilježe se na strani izvora računa opće države, dok se prihodi pod nazivom ostale subvencije za proizvodnju (primljene) prikazuju na uporabnoj strani u računima opće države. Rashode države čine intermedijarna potrošnja, bruto investicije, naknade zaposlenicima, ostali porezi na proizvodnju (plaćeni), vlasnički dohodak (plaćen), tekući porezi na dohodak, bogatstvo itd., socijalne naknade osim socijalnih transfera u naturi, socijalni transferi u naturi - kupljena tržišna proizvodnja, ostali tekući transferi, prilagodba za promjene u mirovinskim pravima, kapitalni transferi (plaćeni) i stjecanje umanjeno za otudenje neproizvedene aktive. Ti se rashodi prikazuju na uporabnoj strani računa opće države, osim plaćenih subvencija koje se bilježe na strani izvora računa opće države. Pozitivna je razlika između prihoda i rashoda opće države neto pozajmljivanje $(+)$, dok je neto uzajmljivanje (-) sektora opće države prisutno kada rashodi nadilaze visinu prikupljenih prihoda opće države (Regulation (EU) No 549/2013, str. 316-317). 
Iz vrijednosti ukupnih prihoda i rashoda opće države moguće je iščitati kako su ukupni prihodi i rashodi, iskazani udjelom u BDP-u, prema metodologiji ESA 2010 veći u odnosu na prethodnu metodologiju ESA 95.

Grafikon 1. Usporedba ukupnih prihoda i rashoda opće države prema metodologijama ESA 95 i ESA 2010, izraženi kao \% BDP-a

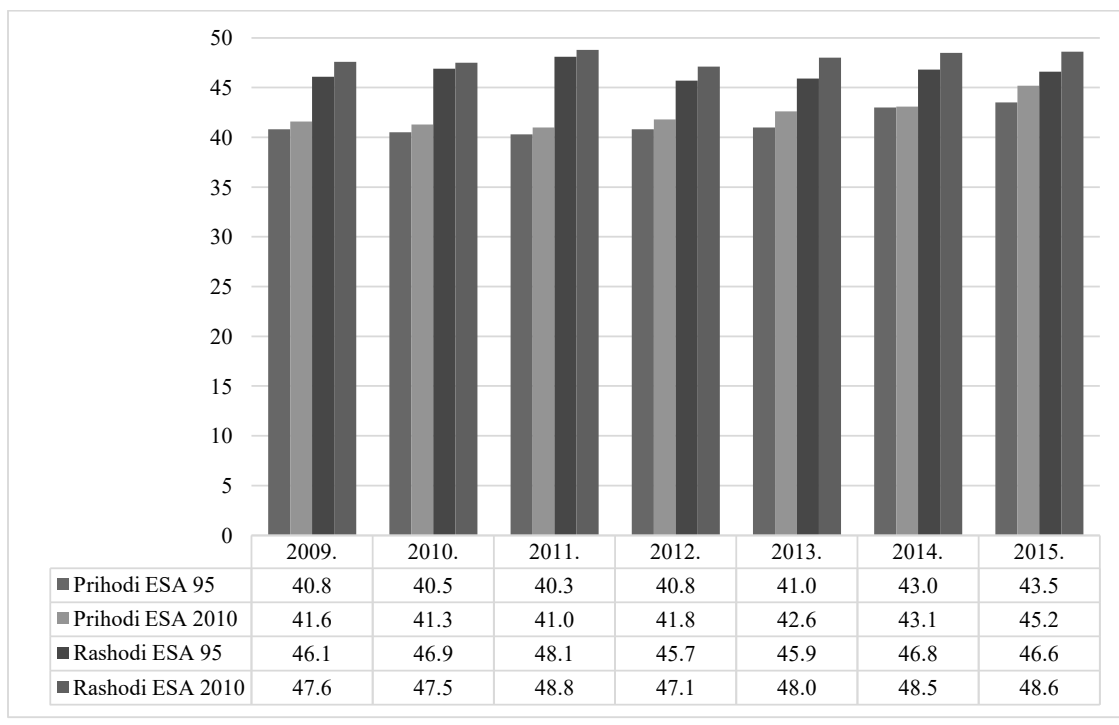

Napomena: Podatci prema ESA 95 za 2014. i 2015. su prognozirani.

Izvor: autorice, prema European Commission (2014, str. 103; 2017, str. 99)

Razlika između ukupnih prihoda izraženih udjelom u BDP-u prema metodologijama ESA 95 i ESA 2010 od 2009. do 2015. kreće se u rasponu od 0,1 do 1,7 postotnih bodova, dok se razlika između ukupnih rashoda u istome razdoblju kreće u rasponu od 0,6 do 2,1 postotnog boda.

$\mathrm{S}$ obzirom na to da je primjena nove metodologije utjecala i na izračun BDP-a, Grafikon 2. prikazuje vrijednosti ukupnih prihoda i rashoda opće države iskazane u milijardama kuna. Promatrano u apsolutnoj vrijednosti, razlika između ukupnih prihoda izraženih u milijardama kuna prema metodologijama ESA 95 i ESA 2010 od 2009. do 2015. kreće se u rasponu od 0 do 5,9 milijarda kuna, dok se razlika između ukupnih rashoda u istome razdoblju kreće u rasponu od 3,8 do 7,3 milijarde kuna. 
Grafikon 2. Usporedba ukupnih rashoda i priboda opće države prema metodologijama ESA 95 i ESA 2010, izraženi u mlrd. kuna

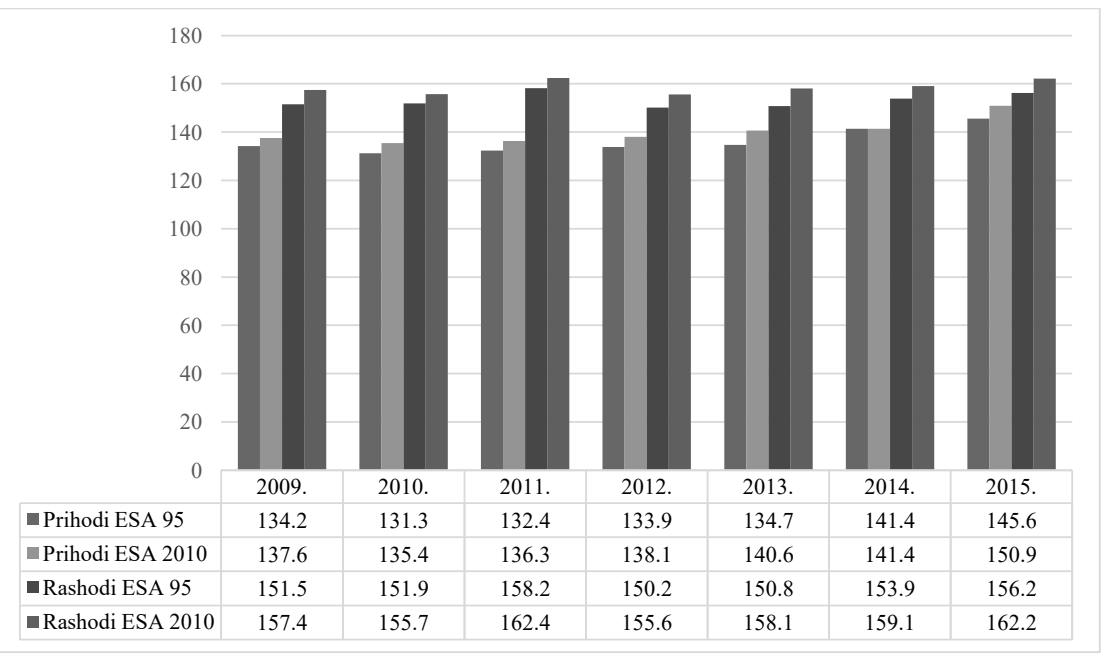

Napomena: Podatci prema ESA 95 za 2014. i 2015. su prognozirani.

Izvor: autorice prema European Commission (2014, str. 102; 2017, str. 98)

Najveći rast prihoda i rashoda, do kojeg je došlo promjenom metodologije u promatranom razdoblju od 2009. do 2015., bilježi se 2013. Prema novoj metodologiji ESA 2010 nema više prilagodba za tretman tijekova kamata iz swap i forward ugovora. Također, na prihodovnoj strani važno je spomenuti reviziju poreznih prihoda. Najvažniji dio navedene revizije odnosi se na promjenu koncepta poreznih prihoda te primjenu posebnih smjernica Eurostata, što je rezultiralo dopunom liste prihoda koji se smatraju porezima. Lista poreznih prihoda tako je dopunjena premijama osiguranja depozita DAB-a te s nekoliko poreza na lutriju, igre na sreću i oklade. Međutim, ukupna revizija poreza nije znatno utjecala na smanjenje deficita jer je najvažnija stavka povećanja poreznih prihoda, premija osiguranja depozita, povećala rashode za isti iznos preko kategorije plaćenih tekućih transfera te je njezin utjecaj na deficit jednak nuli. Prema metodologiji ESA 2010 udio prihoda od PDV-a koji zemlje članice uplaćuju u proračun EU-a ne prikazuje se više zasebno, nego se uključuje u ukupne prihode od PDV-a zemlje članice. Budući da se u obliku raznih tekućih transfera za isti iznos ujedno povećava i rashodna strana, ni ta stavka nije imala utjecaj na deficit (DZS, 2014b).

Utjecaj revizije podataka pokazuje razlika u saldu konsolidiranog proračuna opće države, a upravo visina proračunskoga manjka i razina duga 
konsolidirane opće države dva su glavna kriterija fiskalnog nadzora uspostavljena Ugovorom iz Maastrichta. Konsolidirani proračun opće države prikazuje koliko je stvarno javnih sredstava prikupljeno i potrošeno u čitavoj državi (Ott et al., str. 54). Saldo proračuna konsolidirane opće države razlika je između ukupnih prihoda i ukupnih rashoda te prikazuje proračunski manjak ili višak, odnosno neto uzajmljivanje ili neto pozajmljivanje sektora opće države, kako je definirano sustavom ESA 2010. Promjena određenih stavaka zbog revizije podataka odrazila se na odstupanje visine deficita u promatranom razdoblju.

Grafikon 3. Saldo proračuna konsolidirane opće države u Republici Hrvatskoj u skladu s metodologijama ESA 95 i ESA 2010, izražen u mlrd. kuna i kao $\% B D P-a$

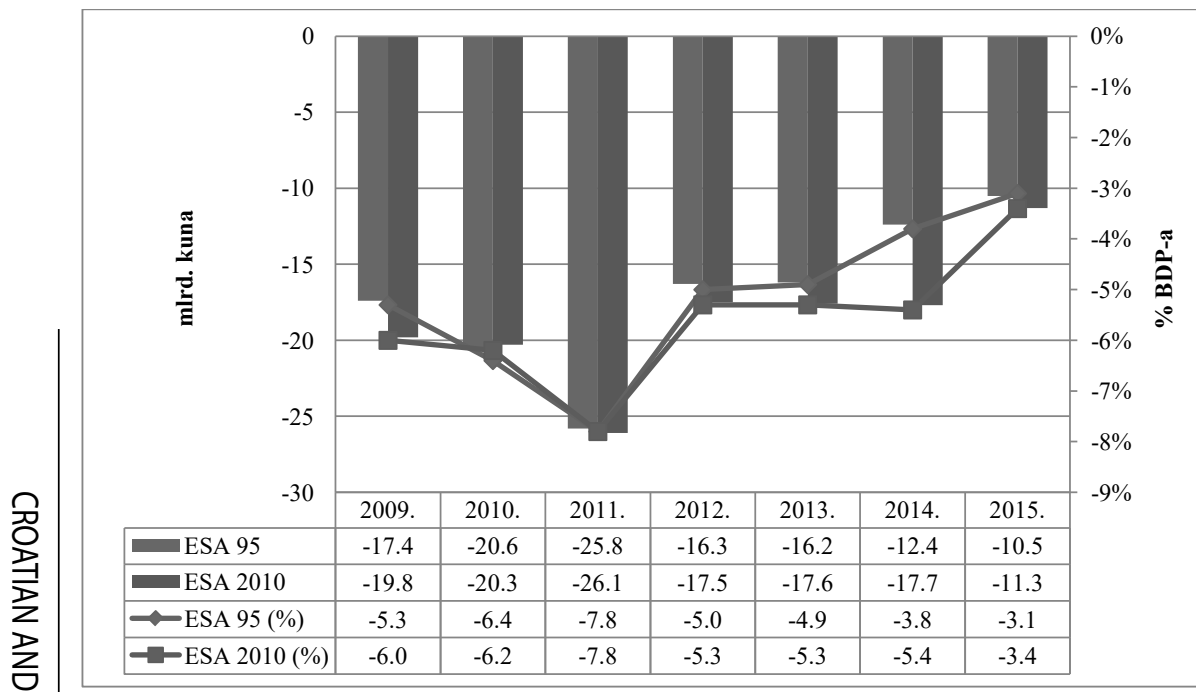

Napomena: Podatci prema ESA 95 za 2014. i 2015. su prognozirani.

Izvor: autorice prema European Commission (2014, str. 102-103; 2017, str. 98-99)

Saldo proračuna konsolidirane opće države izražen udjelom u BDP-u pokazuje da je proračunski manjak opće države u promatranome razdoblju prema ESA 2010 uglavnom bio veći u odnosu na prethodnu metodologiju ESA 95, pri čemu ta razlika doseže 1,6 postotnih bodova u 2014. (Grafikon 3.). Zanimljivo je istaknuti da je 2010. manjak proračuna opće države bio veći prema metodologiji ESA 95 za 0,2 postotna boda u odnosu na manjak prema ESA 2010, odnosno 0,3 milijarde kuna. Najveći manjak zabilježen je 2011. godine te je prema objema metodologijama iznosio 
7,8 \% BDP-a. Iz Grafikona 3. uočava se kako te godine ne postoji razlika proračunskog manjka opće države promatranog udjelom u BPD-u. Međutim, ako iznose promatramo u apsolutnoj vrijednosti, ta je razlika za 2011. iznosila oko 300 milijuna kuna.

Razlika između salda proračuna konsolidirane opće države prema navedenim metodologijama izražena u apsolutnoj vrijednosti kreće se u rasponu od -0,3 do 5,3 milijarde kuna. Primjenom nove metodologije ESA 2010 najveći utjecaj na povećanje deficita u 2013. imalo je uključivanje Hrvatskih autocesta i Autoceste Rijeka - Zagreb u obuhvat opće države u iznosu od 337 milijuna kuna te revizija bruto investicija u fiksni kapital u iznosu od 461 milijun kuna. Podatci o bruto investicijama u fiksni kapital smatraju se preliminarnima sve do obračuna prema podatcima iz Godišnjeg izvještaja o investicijama u dugotrajnu imovinu te je u skladu s time revizija bruto investicija u fiksni kapital utjecala na povećanje deficita (DZS, 2014b). Transfer mirovinskih sredstava iz stupa kapitalizirane štednje u prvi stup u državnom se proračunu tretirao kao (gotovinski) prihod, što nije u skladu s pravilima metodologije ESA 2010 (Europska komisija, 2016). Upravo je statistički tretman transfera socijalnih doprinosa iz II. u I. mirovinski stup najviše utjecao na deficit proračuna opće države u 2014. i 2015. Prema statističkim pravilima ta transakcija ne priznaje se kao prihod u trenutku primitka te je deficit uvećan za 3,069 milijarde kuna u 2014. godini (DZS, 2015a), odnosno za 1,264 milijarde kuna u 2015. (DZS, 2016).

\section{2. Kretanje javnoga duga prema metodologiji ESA 2010}

Fiskalni nadzor Europske komisije nad zemljama članicama temelji se na Izvješću o prekomjernome proračunskom manjku i razini duga opće države koji se podnosi Europskoj komisiji dva puta godišnje, na kraju ožujka (travanjsko izvješće) i na kraju rujna (listopadsko izvješće). Nacionalni statistički uredi obvezni su objaviti Izvješće na svojim internetskim stranicama, koje se odnosi na posljednje četiri godine i za tekuću godinu, pri čemu se podatci za tekuću godinu temelje na prognozama Ministarstva financija (DZS, 2015b). Kriteriji fiskalnog nadzora uspostavljeni Ugovorom iz Maastrichta podrazumijevaju da udio proračunskoga manjka (deficita) opće države zemlje članice ne smije biti veći od 3 \% BDP-a, a konsolidirani dug opće države ne smije prelaziti 60 \% BDP-a (DZS, 2016). Među temeljnim namjenama primjene metodološkog okvira ESA 2010 predviđeno je definiranje kriterija konvergencije za ulazak u eurozonu te 
definiranje kriterija za postupak ili proceduru u slučaju prekomjernoga deficita na temelju izračuna salda proračuna opće države i visine javnog duga (Eurostat, 2013, str. 4).

Prema ESA 2010, javni dug odnosi se na bruto nominalnu vrijednost konsolidiranog duga opće države na kraju godine te obuhvaća ukupne obveze nastale na temelju financijskih instrumenata koji uključuju gotovinu i depozite, dužničke vrijednosne papire te kredite i zajmove (Eurostat, 2018). Izračun manjka općeg proračuna u skladu s konceptima ESA 2010 te pravilima Eurostatova Priručnika o državnom manjku i dugu razlikuje se od izračuna po nacionalnoj metodologiji (računskom planu proračuna i obuhvatu proračunskih i izvanproračunskih korisnika). Također, razlike su znatnije nego prije kod primjene metodologije ESA 95. Primjenom kriterija metodologije ESA 2010 pojedini subjekti koji nisu proračunski ili izvanproračunski korisnici, nego imaju status npr. javnih poduzeća, statistički pripadaju sektoru države. Svojim viškovima odnosno manjkovima te jedinice pojedinačno imaju različit utjecaj na statistički saldo proračuna opće države te posljedično na razinu javnoga duga. Zbog povećanja obuhvata podsektora središnje države došlo je do povećanja duga opće države jer su primljeni krediti reklasificiranih jedinica ušli u obuhvat javnoga duga. Iako su razlike prisutne i kod podsektora lokalne države i fondova socijalne sigurnosti, te promjene nisu toliko bitne kao promjene obuhvata središnje države (Ministarstvo financija, 2015).

Uz promjene sektorskog obuhvata opće države, Ministarstvo financija (2015, str. 30-31) navodi statističke tretmane određenih transakcija prema aktualnoj europskoj statističkoj metodologiji, koji su imali bitan utjecaj na visinu proračunskoga manjka i javnoga duga. Daljnje promjene koje su utjecale na izračun manjka općeg proračuna statističko su tretiranje stjecanja financijske imovine od koje se ne može ostvariti povrat kao rashoda - kapitalnog transfera koji povećava manjak, npr. kupnje dionica ili udjela u poduzeću u gubitcima, ili ulaganja u osnivački kapital subjekta od kojega nije moguće povlačiti dobit. Kao rashod - kapitalni transfer koji povećava manjak statistički se tretira i svako plaćanje po pozvanom jamstvu gdje je jamac država, bez obzira na njegovo iskazivanje prema računovodstvenim standardima kao financijske imovine u obliku potraživanja od prvobitnog dužnika. Također, propisano je statističko preuzimanje cjelokupnoga preostalog iznosa svih dugova jednog subjekta za koje je jamčila država ako u tri godine, koje ne moraju biti uzastopne, dođe do plaćanja po pozvanom jamstvu za tog subjekta, bez obzira na nepostojanje pravnog akta o preuzimanju. Ukupni preuzeti iznos duga u tom je slučaju također rashod - kapitalni transfer koji povećava manjak, a istodobno i povećava 
dug opće države, dok se daljnja plaćanja po pozvanima jamstvima tretiraju kao otplata duga države. Ako se pravnim aktom regulira preuzimanje duga prije nastupanja treće godine poziva jamstva, tada nema automatizma preuzimanja svih jamčenih dugova, ali je za preuzeti dio duga tretman kapitalnog transfera i uključivanja u dug opće države jednak (Ministarstvo financija, 2015, str. 30-31).

Grafikon 4. Dug konsolidirane opće države prema metodologijama ESA 95 i ESA 2010, izražen kao \% BDP-a

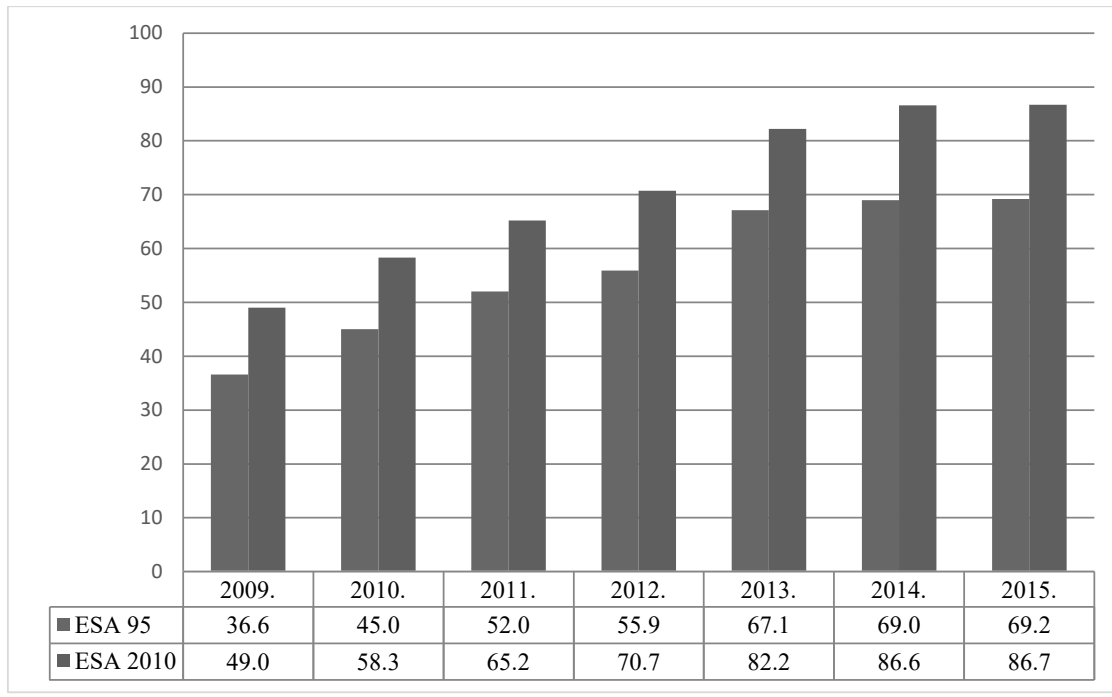

Napomena: Podatci prema ESA 95 za 2014. i 2015. su prognozirani.

Izvor: autorice prema European Commission (2014, str. 105; 2017, str. 101)

Dug konsolidirane opće države prema metodologiji ESA 2010 veći je u odnosu na prethodnu metodologiju ESA 95, a ta se razlika kreće u rasponu od 12,4 do 17,6 postotnih bodova (Grafikon 4.). Najveća razlika vrijednosti duga konsolidirane opće države između metodologija ESA 95 i ESA 2010 zabilježena je 2014. Najveći iznos duga konsolidirane opće države zabilježen je 2015. te je prema metodologiji ESA 95 iznosio 69,2 \% BDP-a, odnosno 86,7 \% BDP-a prema ESA 2010. Od 2009. do 2015. očita je tendencija rasta javnoga duga. U navedenome razdoblju prema metodologiji ESA 95 dug konsolidirane opće države porastao je za 32,6 postotnih bodova, dok je taj rast prema metodologiji ESA 2010 iznosio 37,7 postotnih bodova. ESA 2010 utjecala je na reklasifikaciju nekoliko visokozaduženih poduzeća u državnom vlasništvu unutar sektora opće 
države, što je imalo znatan utjecaj na razinu duga opće države. Najveći učinak na dug opće države imala je resektorizacija javnih poduzeća iz cestovnoga prometa, Hrvatskih autocesta i Autoceste Rijeka - Zagreb, čime se udio javnoga duga u BDP-u povećao u prosjeku za oko 9 postotnih bodova od 2008. do 2013. (Ministarstvo financija, 2015, str. 28). Upravo je zbog toga revizija visine javnoga duga izražena udjelom u BDP-u za 2013. bila najizraženija u Hrvatskoj u odnosu na sve ostale članice Europske unije (Eurostat, 2014c, str. 6). Naknadnim uključivanjem Hrvatske banke za obnovu i razvitak u obuhvat opće države javni dug dodatno je porastao za 4,4 \% BDP-a (DZS, 2015a).

Troškovi koji se odnose na realizaciju potencijalnih rizika bili su vrlo važan čimbenik rasta duga jer se odnose na dio duga koji je Vlada preuzela na temelju učestalih aktiviranja jamstava odobrenih javnim poduzećima (Europska komisija, 2016) i brodogradilištima. Od 2011. do 2014. iznosi preuzetog duga po osnovi trećega poziva po jamstvu ili po ugovoru iznosili su ukupno 8,837 milijarda kuna, pri čemu se većina toga iznosa odnosila na dugove brodogradilišta, dok je manji dio uključivao preuzimanje duga HŽ Carga i HŽ Putničkoga prijevoza (Ministarstvo financija, 2015). Preuzimanje duga Imunološkoga zavoda, HŽ Carga i HŽ Putničkoga prijevoza po osnovi trećega poziva po jamstvu utjecalo je na povećanje deficita i duga opće države u iznosu od 992 milijuna kuna u 2015. (DZS, 2016).

Kada se na temelju detaljne analize zaključi da projekti proizišli iz poslova kao što su javno-privatna partnerstva, koncesije i sl. statistički ulaze u bilancu države, tada su njihovi prihodi i rashodi prihodi i rashodi države te utječu na visinu proračunskoga salda. Stoga, zaključivanje takvih poslova ili izmjena postojećih ugovora zahtijevaju njihovo preispitivanje kako bi se utvrdio odgovarajući statistički tretman (Ministarstvo financija, 2015, str. 31). Neka ulaganja provedena u okviru projekta javno-privatnoga partnerstva izvan državnoga proračuna vraćena su u državni proračun te tako i u saldo proračuna opće države nakon revizije temeljnih rizika u skladu s računovodstvenim pravilima metodologije ESA 2010 (Europska komisija, 2016). Statističkim evidentiranjem projekta Bina Istra d. d. u bilanci opće države javni je dug od 2012. do 2014. porastao u prosjeku za 4,7 milijarda kuna (DZS, 2016). Nagli rast duga opće države od 2009. do 2014. prouzročen je negativnim gospodarskim kretanjima u kombinaciji s restrukturiranjem pojedinih sektora, znatnim preuzimanjem obveza javnih poduzeća te akumulacijom proračunskih manjkova (Ministarstvo financija, 2015, str. 28). 


\section{Diskusija}

Statistički podatci o stanju državnih financija jako su važni ne samo za ocjenu vođenja fiskalne politike nego su i ključni pokazatelji za ocjenu kreditnoga rejtinga zemlje te su sastavni dio izvještaja bitnih za fiskalni nadzor koji Europska komisija provodi nad zemljama članicama kako bi se očuvala fiskalna stabilnost unutar Europske unije. Analiza sadržana u prethodnome dijelu rada pokazuje da su podatci pod velikim utjecajem primijenjene metodologije, koja se odnosi na sustav prikazivanja nacionalnih i regionalnih računa.

Primjenom nove metodologije ESA 2010 u Hrvatskoj došlo je do znatna odstupanja visine javnoga duga izražene udjelom u BDP-u u odnosu na objavljene podatke prema prethodnoj metodologiji ESA 95 u visini od 12 do 17 postotnih bodova. Ta odstupanja bila su veća u odnosu na odstupanja u Irskoj, koja je također bilježila znatno povećanje javnoga duga zbog promjena prouzročenih uvođenjem nove metodologije. Iako je u Belgiji također došlo do reklasifikacije velika broja institucijskih jedinica u sektor opće države, odstupanja javnoga duga u Hrvatskoj bila su puno veća u odnosu na Belgiju u kojoj se udio duga u BDP-u povećao za 2,9 do 3,3 postotna boda od 2010. do 2013. Za razliku od navedenih zemalja, uvođenje nove metodologije rezultiralo je smanjenjem udjela javnoga duga u BDPu u Finskoj zbog pozitivna učinka revizije podataka o BDP-u. Pritom treba naglasiti da se u 2010. godini Finska isticala među zemljama EU-a po razini povećanja razine BDP-a (4,2 \%) zbog metodoloških promjena, pri čemu je to povećanje proizišlo iz ulaganja u istraživanje i razvoj (4 \%).

Istodobno se Hrvatska nalazila u društvu zemalja s najmanjim utjecajem metodoloških promjena na razinu BDP-a jer je to povećanje u Hrvatskoj i Malti iznosilo tek 0,5 \%, a u Bugarskoj 0,4 \%, odnosno ulaganja u istraživanje i razvoj doprinijela su povećanju BDP-a navedenih zemalja u iznosu od 0,3 do $0,5 \%$ (Eurostat, 2019). U tome kontekstu metodološke promjene (engl. methodological changes) odnose se na tretiranje izdataka za istraživanje i razvoj te izdataka za vojnu opremu kao investicija, dok najvažnija statistička poboljšanja (engl. statistical improvements) povezana s uvođenjem metodologije ESA 2010 obuhvaćaju nove i poboljšane izvore podataka, uključivanje ilegalnih aktivnosti u službeni BDP i poboljšanja specifična za pojedinu zemlju (Eurostat, 2019). U Hrvatskoj su ukupni učinci implementacije nove metodologije na povećanje razine BDP-a bili prilično mali (oko $1,2 \% \mathrm{u}$ prosjeku) ${ }^{3}$ te nisu mogli znatno ublažiti naglo povećanje relativnog iznosa duga opće države.

3 Prema podatcima DZS-a revidirani BDP u tekućim cijenama od 1995. do 2012. povećao se u prosjeku za 1,2\% (DZS, 2014c, str. 10). 
Ograničenje te analize proizlazi iz toga što je najveće odstupanje zabilježeno u godinama u kojima se mjeri odstupanje između prognoziranih podataka o proračunskome manjku i javnome dugu za 2014. i 2015. godinu prema ESA 95 te stvarnih podataka za navedene godine prema metodologiji ESA 2010. Međutim, čak i kada se zanemare navedene godine, prisutno je vrlo visoko povećanje javnoga duga koje iznosi do 15 postotnih bodova. Potrebno je naglasiti i da su konačni podatci o visini javnoga duga koje je u svojim izvještajima objavila Europska komisija u skladu s podatcima koje je objavljivao Državni zavod za statistiku u Izvješćima o prekomjernome proračunskome manjku i razini duga opće države u Republici Hrvatskoj, kao i s podatcima o javnome dugu prema ESA $2010 \mathrm{za}$ promatrano razdoblje koje je objavilo Ministarstvo financija u Strategiji upravljanja javnim dugom 2017. - 2019. navodeći kao izvor HNB i DZS (2017b, str. 10). Iz navedenoga se može zaključiti da je riječ o službenim podatcima te se na temelju njih može prikazati ukupan utjecaj promjene metodologije na povećanje službenih podataka o visini javnoga duga.

Ako se promotre vrijednosti deficita i duga opće države, razvidno je da je i prema metodologiji ESA 95 i ESA 2010 Hrvatska u promatranom razdoblju premašivala referentnu vrijednost deficita proračuna opće države. Također, projekcije su upućivale na to da će u 2014. godini i visina duga prekoračiti referentnu vrijednost te je u skladu s Paktom o stabilnosti i rastu (Angerer, 2015) pokrenut postupak u slučaju prekomjernoga proračunskog manjka 2014. godine (Council Decision 2014/56/EU, str. 13). Iako je Europska komisija razmotrila relevantne čimbenike, koji su uključivali duboku i dugotrajnu recesiju te nepovoljna zbivanja u okruženju, konačno je zaključeno da javni dug nije zadovoljio kriterij propisan Ugovorom o funkcioniranju Europske unije, odnosno Protokolom o postupku u slučaju prekomjernog deficita (čl. 1.). Na temelju podataka dostavljenih Eurostatu, Programa konvergencije 2017. - 2020. i prognoziranih podataka Europske komisije doneseni su zaključci na temelju kojih je 2017. zatvoren postupak u slučaju prekomjernoga proračunskog manjka. Deficit proračuna opće države 2016. iznosio je 0,8 \% BDP-a, što je znatno smanjenje u odnosu na prethodnu godinu kada je iznosio 3,4 \% BDP-a. Poboljšanje je ostvareno povećanjem proračunskih prihoda zbog gospodarskoga rasta i ograničavanjem proračunskih rashoda. Na taj način deficit je sveden na razinu ispod $3 \%$ u okviru roka koje je Vijeće EU-a odredilo. Planirane vrijednosti deficita iznosile su 1,3\% BDP-a u 2017. i $0,8 \%$ u 2018. godini, što je ispod referentne vrijednosti (Council Decision (EU) 2017/1191, str. 8). Visina javnoga duga dosegnula je vrhunac 2015. s $86,7 \%$ BDP-a te se iduće godine smanjila na 84,2 \% (DZS, 2017), a 
prema prognozama Europske komisije predvideno je daljnje smanjenje duga na 79,4 \% u 2018. (Council Decision (EU) 2017/1191, str. 9). U skladu s kretanjem manjka proračuna i duga konsolidirane opće države, u lipnju 2017. godine Vijeće za ekonomske i financijske poslove službeno je potvrdilo da je Hrvatska ispunila uvjete za izlazak iz postupka u slučaju prekomjernoga proračunskog manjka. Ministarstvo financija navodi da je to rezultat napora vezanih za fiskalnu konsolidaciju zbog čega su ostvareni i bolji rezultati od preporuka Europske komisije (Ministarstvo financija, 2017a). Navedeno potvrđuju i podatci za 2017. iz kojih se očituje da je Hrvatska ostvarila suficit proračuna opće države u iznosu od 0,8 \% BDP-a te je udio javnoga duga u BDP-u smanjila za 2,6 postotna boda (European Commission, 2018, str. 99, 101). Nova revizija podataka o javnome dugu, u skladu s metodologijom ESA 2010, rezultirala je smanjenjem razine javnoga duga s prosječnim utjecajem na smanjenje duga od 1,89 \% BDP-a od 2014. do 2018. (DZS, 2018). Prema prognozama Europske komisije (European Commission, 2018) nastavak povoljnih trendova u provođenju fiskalne politike trebao bi rezultirati ostvarivanjem suficita salda proračuna konsolidirane opće države te daljnjim smanjenjem razine javnoga duga mjerene udjelom u BDP-u u 2018. i 2019.

Važno je istaknuti da usklađivanje s novom metodologijom nije završilo, zbog čega se podatci o javnome dugu još mijenjaju, odnosno u 2018. godini dolazi do korekcije i smanjenja visine javnoga duga za cijelu seriju podataka zbog konsolidacije na razini instrumenta dužničkih vrijednosnih papira. Kada se promatraju podatci Statističkoga ureda Europske unije od 2008. do 2015. objavljeni u srpnju 2019., tada je moguće primijetiti da odstupaju od navedenih podataka u rasponu od 0,6 do 3 postotna boda u smislu nižih vrijednosti javnoga duga u odnosu na podatke objavljene u 2017. Također, dolazi do proširenja obuhvata sektora opće države uključivanjem poduzeća u likvidaciji i komunalnih poduzeća u 2015. i 2016. (Krištof, 2018). Obuhvat sektora opće države ponovno se proširuje u travnju 2019. uključivanjem brojnih javnih poduzeća koja su pala test tržišnosti u dvije uzastopne godine, kao i poduzeća koja su na temelju kvalitativnih kriterija uključena u sektor države, čime su obuhvaćene i sve turističke zajednice (DZS, 2019). Podatke o javnome dugu potrebno je promatrati u kontekstu obuhvata sektora opće države, koji je od primjene nove metodologije dinamičan segment javnoga sektora. ${ }^{4}$ Unatoč varijaci-

4 „Od primjene ESA 2010 metodologije do 11. srpnja 2019. reklasificirane su ukupno 662 jedinice, što na temelju kvalitativnih kriterija, što na temelju testa tržišnosti, kao i korekcija pogrešne inicijalne sektorizacije." (Janko Kraševac, viši stručni savjetnik u Državnom 
jama podataka moguće je zaključiti da je u Hrvatskoj došlo do iznimno velika povećanja javnoga duga koje najvećim dijelom proizlazi iz primjene nove sektorske klasifikacije institucija opće države, zbog čega je došlo i do reklasifikacije triju javnih poduzeća s visokom razinom zaduženosti u sektor središnje države, a njihov ukupan dug na kraju 2015. prema podatcima Ministarstva financija (2017b, str. 8) iznosio je 45,2 milijarde kuna. Imajući u vidu kretanje nominalnoga BDP-a u promatranome razdoblju od 2008. do 2015., ukupan dug tih poduzeća iznosio je oko 13 \% BDP-a.

\section{Zaključak}

Hrvatska je s članstvom u Europskoj uniji preuzela obvezu dostavljati Europskoj komisiji izvještaje o stanju svojih javnih financija u skladu s metodologijom Europskoga sustava nacionalnih i regionalnih računa. ESA 2010 nova je metodologija koja se upotrebljava u proizvodnji i dostavi podataka o nacionalnim računima kako bi se uspostavila usklađenost i usporedivost podataka u okviru Europske unije prema europskim standardima. Koncepti utvrđeni metodologijom ESA 2010 posebno su važni jer služe kao polazište statističkih mjerenja državne i cjelokupne gospodarske aktivnosti u funkciji ostvarenja makroekonomske stabilnosti te omogućavaju usporedivost podataka s drugim članicama Europske unije.

Uvođenje i primjena nove metodologije ESA 2010 bitno je utjecala na statistiku javnih financija u Hrvatskoj, odnosno na podatke o kretanju prihoda, rashoda i salda proračuna opće države te razinu duga konsolidirane opće države. Reklasifikacijom dijela javnih poduzeća iz podsektora nefinancijskih i financijskih javnih društava u podsektor središnje države došlo je do povećanja razine javnoga duga, pri čemu je najveći utjecaj imala reklasifikacija Hrvatskih autocesta, Autoceste Rijeka - Zagreb i Hrvatske banke za obnovu i razvitak. Istodobno su se potencijalne obveze države u obliku izdanih jamstava naglo smanjile jer je država velikim dijelom jamčila upravo za dugove navedenih društava, pa su reklasifikacijom te potencijalne obveze pretvorene u izravne obveze države.

Na deficit proračuna opće države velik je utjecaj imao i statistički tretman transfera socijalnih doprinosa iz drugoga u prvi mirovinski stup. Poveća-

zavodu za statistiku, elektroničkom poštom 11. srpnja 2019.). Slična je situacija bila u Belgiji, gdje je analiza sektorske klasifikacije više od 1400 jedinica rezultirala reklasifikacijom gotovo 700 jedinica u sektor opće države do 30. rujna 2014. (National Bank of Belgium, 2014, str. 45). 
nju duga dodatno je pridonijelo preuzimanje dugova na temelju učestalih aktiviranja odobrenih državnih jamstava te statistički tretman određenih projekata javno-privatnoga partnerstva i koncesija. Osim preuzimanja obveza javnih poduzeća, visini proračunskoga manjka u promatranom razdoblju doprinijela su i nepovoljna gospodarska kretanja, što je rezultiralo naglim rastom duga opće države. Iako se naglo povećanje javnoga duga nije povoljno odrazilo na sliku o fiskalnoj održivosti i makroekonomskoj stabilnosti, primjena metodologije ESA 2010 omogućila je bolji uvid u financijski položaj javnoga sektora te je uslijedio napredak u vođenju državnih financija. Hrvatska je nakon trogodišnjega razdoblja, na temelju poboljšanih fiskalnih i gospodarskih rezultata, 2017. godine izišla iz postupka u slučaju prekomjernoga proračunskog manjka.

\section{Literatura}

Andabaka, A., Družić, I., \& Mustać, N. (2017). Pokretači javnoga duga u Hrvatskoj. Ekonomski pregled, 68(5), 463-487. Preuzeto s mrežne stranice https:// hrcak.srce.hr/190456.

Angerer, J. (2015). Stability and growth pact - an overview of the rules. Preuzeto s mrežne stranice http://www.europarl.europa.eu/RegData/etudes/note/ join/2014/528745/IPOL-ECON_NT(2014)528745_EN.pdf.

Bajo, A., \& Juričić, D. (2015). Kada obveze iz ugovora o javno-privatnom partnerstvu i koncesijama postaju dio duga opće države? Newsletter, No. 101. doi: 10.3326/nlh.2015.101.

Casey, E. (2014). Analytical note no. 6: adoption of new international standards for national accounts and balance of payments. Irish Fiscal Advisory Council. Preuzeto s mrežne stranice https://www.fiscalcouncil.ie/wp-content/uploads/2012/01/AN-ESA-Revisions-5-Final.pdf.

DZS (2014a). Sektorska klasifikacija institucionalnib jedinica. Preuzeto s mrežne stranice https://www.dzs.hr/app/sektorizacija/Documentation/SektorskaKlasifikacijaESA2010.pdf.

DZS (2014b). Izvješće o prekomjernome proračunskome manjku $i$ razini duga opće države u Republici Hrvatskoj, listopad 2014. (ESA 2010). Priopćenje, 12.1.3/2. Preuzeto s mrežne stranice http://www.dzs.hr/Hrv_Eng/publication/2014/12-01-03_02_2014.htm.

DZS (2014c). Revizija bruto domaćeg proizvoda prema ESA 2010 metodologiji. Preuzeto s mrežne stranice https://www.dzs.hr/Hrv/important/PressCorner/ Prezentacije/Prezentacija_BDP_ESA_2010_10_09_2014.pdf.

DZS (2015a). Izvješće o prekomjernome proračunskome manjku i razini duga opće države u Republici Hrvatskoj, travanj 2015. (ESA 2010). Priopćenje, 12.1.2/1. Preuzeto s mrežne stranice http://www.dzs.hr/Hrv_Eng/publication/2015/12-01-02_01_2015.htm. 
DZS (2015b). Izvješće o prekomjernome proračunskome manjku $i$ razini duga opće države u Republici Hrvatskoj, listopad 2015. (ESA 2010). Priopćenje, 12.1.2/2. Preuzeto s mrežne stranice http://www.dzs.hr/Hrv_Eng/publication/2015/12-01-02_02_2015.htm.

DZS (2016). Izvješće o prekomjernome proračunskom manjku i razini duga opće države u Republici Hrvatskoj, listopad 2016. (ESA 2010). Priopćenje, 12.1.2/2. Preuzeto s mrežne stranice https://www.dzs.hr/Hrv_Eng/publication/2016/12-01-02_02_2016.htm.

DZS (2017). Izvješće o prekomjernome proračunskome manjku $i$ razini duga opće države u Republici Hrvatskoj, travanj 2017. (ESA 2010). Priopćenje, 12.1.2/1. Preuzeto s mrežne stranice https://www.dzs.hr/Hrv_Eng/publication/2017/12-01-02_01_2017.htm.

DZS (2018) Izvješće o Proceduri prekomjernoga proračunskog manjka i razini duga opće države u Republici Hrvatskoj, travanj 2018. (ESA 2010). Priopćenje, 12.1.2/1. Preuzeto s mrežne stranice https://www.dzs.hr/Hrv_Eng/publication/2018/12-01-02_01_2018.htm.

DZS (2019). Izvješće o Proceduri prekomjernoga proračunskog manjka i razini duga opće države u Republici Hrvatskoj, travanj 2019. (ESA 2010.). Priopćenje, 12.1.2/1. Preuzeto s mrežne stranice https://www.dzs.hr/Hrv_Eng/publication/2019/12-01-02_01_2019.htm.

European Commission (2014). General government data - part i: tables by country. Spring 2014. Preuzeto s mrežne stranice http://ec.europa.eu/economy_finance/db_indicators/gen_gov_data/documents/2014/spring2014_country_ en.pdf.

European Commission (2017). General government data - part i: tables by country. Spring 2017. Preuzeto s mrežne stranice https://ec.europa.eu/info/sites/info/ files/gen_gov_data_part_i_spring_2017.pdf.

European Commission (2018). General government data - part i: tables by country. Spring 2018. Preuzeto s mrežne stranice https://ec.europa.eu/info/sites/info/ files/economy-finance/ggd_part_i_spring_2018.pdf.

Europska komisija (2016). Izvješće za Hrvatsku 2016. S detaljnim preispitivanjem o sprječavanju $i$ ispravlianju makroekonomskih neravnoteža. Preuzeto s mrežne stranice https://ec.europa.eu/info/sites/info/files/cr_croatia_2016_hr.pdf.

Eurostat (2013). European system of accounts - ESA 2010. Luxembourg, Luxembourg: Publications Office of the European Union.

Eurostat (2014a). Manual on government deficit and debt: implementation of esa 2010 -2014 edition. Luxembourg, Luxembourg: Publications Office of the European Union. doi: 10.2785/55028.

Eurostat (2014b). Manual on the changes between ESA 95 and ESA 2010 - 2014 edition. Luxembourg, Luxembourg: Publications Office of the European Union. doi: $10.2785 / 52663$.

Eurostat (2014c). Revisions to government deficit and debt of EU Member States for 2010-2013. Preuzeto s mrežne stranice https:/ec.europa.eu/eurostat/documents/1015035/2041365/Revisions-gov-deficit-debt-2010-2013.pdf. 
Eurostat (2018). Government consolidated gross debt by components - annual data. Preuzeto s mrežne stranice https://ec.europa.eu/eurostat/web/products-datasets/-/tipsgo11.

Eurostat (2019). Annual national accounts - how ESA 2010 bas changed the main GDP aggregates. Preuzeto s mrežne stranice https://ec.europa.eu/eurostat/statistics-explained/index.php/Annual_national_accounts_-_how_ESA_2010_ has_changed_the_main_GDP_aggregates\#Impact_on_the_level_and_ growth_rates_of_EA.E2.80.9118_and_EU.E2.80.9128_GDP, https://doi. org/10.18356/2fd8209b-en

Galinec, D., \& Kandžija, T. (2018). The impact of stock-flow adjustments on changes in Croatian general government debt level. Zbornik radova Ekonomskog fakulteta Sveučilišta u Mostaru, (Special Issue 2018.), 214-227. Preuzeto s mrežne stranice https://hrcak.srce.hr/221518.

Hansen, T., El Rayess, M., Irwin, T., \& Seiwald, J. (2015). Finland: fiscal transparency evaluation. IMF Country Report No. FO/DIS/15/60. Washington, D. C.: International Monetary Fund, https://doi.org/10.5089/9781498318600.002

HNB (2015). Uvodenje standarda ESA $2010 i$ ostalib promjena u monetarnu $i$ financijsku statistiku HNB-a. Preuzeto s mrežne stranice https://www.hnb.hr/ documents/20182/121822/h-esa-prezentacija-hecimovic.pdf/f5c74039-14154f71-9e03-0f5744b57ed5.

HNB (2016). Bilten 221. Zagreb, Hrvatska: Hrvatska narodna banka.

HNB (2018). Uputa za statističko i nadzorno izvješćivanje ("Narodne novine", br. 85/2018.). Preuzeto s mrežne stranice https://www.hnb.hr/documents/ 20182/2570739/h-uputa-statisticko-i-nadzorno-izvjescivanje_85-2018.pdf/8cdcb7d2-e4f3-4564-bc92-e7d947a0b56a.

Hrvatski sabor (2013). Godišnji izvještaj o primjeni fiskalnih pravila za 2012. godinu. Zagreb, Hrvatska: Narodne novine, 98/13.

Krištof, M. (2014). Izvješće o prekomjernome proračunskome manjku i razini duga opće države, listopad2014. Preuzetos mrežne stranicehttps://www.dzs.hr/Hrv/important/PressCorner/Prezentacije/Prezentacija\%20Izvje\%C5\%A1\%C4\%87e\%20 o\%20prekomjernome\%20prora\%C4\%8Dunskome\%20manjku\%20i\%20razini\%20duga\%20op\%C4\%87e\%20dr\%C5\%BEave\%20(listopadska\%20notifikacija\%202014.).pdf.

Krištof, M. (2015). Izvješće o prekomjernome proračunskome manjku i razini duga opće države. Preuzeto s mrežne stranice http://www.dzs.hr/Hrv/important/ PressCorner/Prezentacije/Prezentacija\%20II\%20April\%202015\%20Izvjesce\%20o\%20prekomjernom\%20proracunskome\%20manjku.pdf.

Krištof, M. (2018). Izvješće o proceduri prekomjernoga proračunskog manjka i razini duga opće države, travanj 2018. Preuzeto s mrežne stranice https://www.dzs. $\mathrm{hr} / \mathrm{hrv} /$ important/presscorner/Prezentacije/Izvjesce\%20o\%20proceduri\%20 prekomjernoga\%20proracunskog\%20manjka\%20-\%20travanj\%202018.pdf.

Ministarstvo financija (2015). Smjernice ekonomske i fiskalne politike za razdoblje 2016. - 2018. Preuzeto s mrežne stranice http://www.mfin.hr/adminmax/ docs/Smjernice\%20eko-nomske\%20i\%20fiskalne\%20politike\%202016.\%20 -\%202018.(29.7.(2).pdf. 
Ministarstvo financija (2017a). Potvrđena odluka o izlasku Hrvatske iz Procedure prekomjernog proračunskog manjka. Preuzeto s mrežne stranice http://www. $\mathrm{mfin} . \mathrm{hr} / \mathrm{hr} /$ novosti/potvrdena-odluka-o-izlasku-hrvatske-iz-procedure-prekomjernog-proracunskog-.

Ministarstvo financija (2017b). Strategija upravljanja javnim dugom za razdoblje 2017. - 2019. Preuzeto s mrežne stranice https://vlada.gov.hr/UserDocsImages/ZPPI/Strategije/Strategija\%20upravljanja\%20javnim\%20dugom\%20 2017-2019\%20-\%2025.1.2017.pdf.

National Bank of Belgium (2014). National accounts ESA 2010: The new reference framework for the national accounts. Brussels, Belgium: National Bank of Belgium.

Ott, K., Bajo, A., Bronić, M., Bratić, V., \& Medak Fell, D. (2009). Proračunski vodič za gradane. Drugo, promijenjeno izdanje. Zagreb, Hrvatska: Institut za javne financije i Zaklada Friedrich Ebert.

Primorac, M., \& Župančić, I. (2016). The structure and economic significance of government guarantees in Croatia and the European Union. Financial theory and practice, 40(1), 63-83. https://doi.org/10.3326/fintp.40.1.2.

\section{Propisi}

Regulation (EU) No 549/2013 of the European Parliament and of the Council of 21 May 2013 on the European system of national and regional accounts in the European Union (OJ 2013, L 174, 26. 6. 2013., str. 1-727)

Council Decision 2014/56/EU of 28 January 2014 on the existence of an excessive deficit in Croatia (OJ 2014, L 36, 6. 2. 2014., str. 13-14)

Council Decision (EU) 2017/1191 of 16 June 2017 abrogating Decision 2014/56/ EU on the existence of an excessive deficit in Croatia (OJ 2017, L 172, 5. 7. 2017., str. 8-9)

Ugovor o Europskoj uniji (pročišćena verzija iz 2016.) i Ugovor o funkcioniranju Europske unije (pročišćena verzija iz 2016.), protokoli, prilozi Ugovoru o funkcioniranju Europske unije, izjave priložene Završnom aktu Međuvladine konferencije na kojoj je donesen Ugovor iz Lisabona potpisan 13. prosinca 2007., tablice ekvivalenata (SL 2016, C 202, 7. 6. 2016., str. 1-388) 


\section{IMPLEMENTATION EFFECTS OF THE EUROPEAN SYSTEM OF ACCOUNTS 2010 ON THE GOVERNMENT FINANCE STATISTICS IN CROATIA}

\section{Summary}

As a member state of the European Union, Croatia is committed to delivering the excessive deficit procedure reports to the European Commission according to the European system of national and regional accounts (ESA 2010) methodology. The implementation of the new methodological framework in September 2014 had a significant effect on government finance data in Croatia. The ESA 2010 methodology is used to measure the government and total economic activity in a country in order to monitor macroeconomic stability and achieve comparability of data with other member states. The aim of this paper is to establish the most significant changes in the scope of the general government and sector classifications of institutional units within the public sector, as well as to quantify the effects of the new methodology implementation on the fiscal position of Croatia between 2009 and 2015. Fiscal indicator deviations are based on the comparative analysis of data pre-approved by Eurostat and provided to the European Commission according to ESA 95 and data delivered after the implementation of the ESA 2010 methodology. A comparison of the methodological frameworks and data indicates significant deviations resulting in increased relative and absolute values of the general government debt, while the implementation of the new methodological framework provides better insight into key fiscal risks and the public sector's financial position. The reclassification of general government sector units contributed substantially to the increase in public debt; affecting in particular Croatian Motorways, Motorway Rijeka-Zagreb, and the Croatian Bank for Reconstruction and Development. The general government budget deficit was also under the strong influence of the statistical treatment of social contribution transfers from the second to the first pension pillar. Furthermore, frequent activation of government guarantees and the statistical treatment of certain public-private partnerships and concessions also added to the public debt. Apart from including the liabilities of state-owned enterprises, the general government deficit was further affected by unfavourable economic conditions. Croatia managed to exit the excessive deficit procedure after three years following an improvement in ber fiscal position due to an increase in government revenues, control of government expenditures and economic growth.

Keywords: ESA 2010, government finance, general government, institutional units, sectoring 